\title{
Hypothalamic and pituitary development: novel insights into the aetiology
}

\author{
Daniel Kelberman and Mehul Tulsidas Dattani \\ Developmental Endocrine Research Group, Institute of Child Health, 30 Guilford Street, London WC1N 1EH, UK \\ (Correspondence should be addressed to M T Dattani; Email: m.dattani@ich.ucl.ac.uk)
}

\begin{abstract}
The anterior pituitary gland is a central regulator of growth, reproduction and homeostasis, and is the end-product of a carefully orchestrated pattern of expression of signalling molecules and transcription factors leading to the development of this complex organ secreting six hormones from five different cell types. Naturally occurring and transgenic murine models have demonstrated a role for many of these molecules in the aetiology of combined pituitary hormone deficiency (CPHD). These include the transcription factors HESX1, PROP1, POU1F1, LHX3, LHX4, TBX19, SOX2 and SOX3. The expression pattern of these transcription factors dictates the phenotype that results when the gene encoding the relevant transcription factor is mutated. The highly variable phenotype may consist of isolated hypopituitarism, or more complex disorders such as septo-optic dysplasia and holoprosencephaly. Since mutations in any one transcription factor are uncommon, and since the overall incidence of mutations in known transcription factors is low in patients with CPHD, it is clear that many genes remain to be identified, and the characterization of these will further elucidate the pathogenesis of these complex conditions and also shed light on normal pituitary development.
\end{abstract}

European Journal of Endocrinology 157 S3-S14

\section{Normal forebrain and pituitary development}

The development of the pituitary gland is highly complex, occurring at a very early stage of embryogenesis, and is closely linked to that of the forebrain. The pituitary is derived from the midline of the anterior neural ridge and the development of the pituitary gland is similar in all vertebrates studied, with the three lobes of the mature gland (anterior, intermediate and posterior) having a dual embryonic origin. The anterior and intermediate lobes of the pituitary are derived from the oral ectoderm, whilst the posterior pituitary originates from neural ectoderm. Development of the anterior pituitary occurs in distinct stages of differentiation and has been extensively studied in the mouse. The juxtaposition of the oral ectoderm forming Rathke's pouch and the neural ectoderm of the diencephalon is maintained throughout the early stages of pituitary organogenesis, and inductive tissue interactions and extrinsic signalling from the neuroectoderm of the infundibulum are critical for the initial development of the pituitary gland (1). A cascade of signalling molecules and transcription factors play crucial roles

This paper was presented at the Ipsen symposium, 'The evolving biology of growth and metabolism', Lisbon, Portugal, 16-18 March 2007. Ipsen has supported the publication of these proceedings. in organ commitment, cell proliferation, cell patterning and terminal differentiation events within the developing pituitary (extensively reviewed elsewhere (2-4)).

In comparison with the rodent, relatively little is known about pituitary development in humans. However, it would appear that several transcription factors involved in the embryological development of the murine pituitary also appear to be involved in human pituitary organogenesis. Spontaneous or artificially induced mutations and gene knockouts in the mouse have led to significant insights into human pituitary disease, with the identification of human mutations in a number of genes that give rise to hypopituitary phenotypes in their respective murine orthologues. Many have been implicated in the aetiology of both murine and human hypopituitarism, including Hes $x$, Lhx3, Lhx4, Prophet of Pit1 (Prop1), Pou1f1 (previously called Pit-1), Pitx2, T-Pit (Tbx19), Sox 2 and Sox3 (Table 1). This review will deal primarily with transcription factors implicated in the aetiology of hypopituitarism in humans as a result of the identification and characterization of mutations within these genes in patients and their respective murine orthologues.

\section{HESX1}

Given the closely linked development of the pituitary gland and forebrain during normal embryogenesis, it is not 
Table 1 Human mutations causing abnormal hypothalamo-pituitary development and function.

\begin{tabular}{|c|c|c|}
\hline Gene & Phenotype & Inheritance \\
\hline \multicolumn{3}{|c|}{ Combined pituitary hormone deficiency $(C P H D)$} \\
\hline POU1F1 & $\mathrm{GH}, \mathrm{TSH}$, prolactin deficiencies; usually severe; small or normal AP & Recessive, dominant \\
\hline PROP1 & $\begin{array}{l}\text { GH, TSH, LH, FSH, prolactin deficiencies; evolving ACTH deficiency; small, normal or } \\
\text { enlarged AP }\end{array}$ & Recessive \\
\hline \multicolumn{3}{|c|}{ Specific syndrome } \\
\hline HESX1 & IGHD, CPHD, septo-optic dysplasia; APH, EPP, absent infundibulum, ACC & Recessive, dominant \\
\hline LHX3 & $\begin{array}{l}\mathrm{CPHD} \text { (GH, TSH, LH, FSH, prolactin deficiencies), short neck, limited rotation; small, } \\
\text { normal or enlarged AP, short cervical spine }\end{array}$ & Recessive \\
\hline LHX4 & CPHD (GH, TSH, ACTH deficiencies); small AP, EPP, cerebellar abnormalities & Dominant \\
\hline SOX3 & IGHD and mental retardation, panhypopituitarism; APH, infundibular hypoplasia, EPP & X Linked \\
\hline SOX2 & $\begin{array}{l}\text { Hypogonadotrophic hypogonadism; APH, bilateral anophthalmia/microphthalmia, abnormal } \\
\text { corpus callosum, learning difficulties, oesophageal atresia, sensorineural hearing loss }\end{array}$ & De novo \\
\hline TBX19 & Neonatal ACTH deficiency & Recessive \\
\hline
\end{tabular}

$\mathrm{AP}(\mathrm{H})$, anterior pituitary (hypoplasia); EPP, ectopic posterior pituitary; ACC, agenesis of corpus callosum.

surprising that abnormalities of the two structures can be linked in human disease. Septo-optic dysplasia (SOD), often referred to as de Morsier syndrome (5), is a rare, highly heterogeneous condition initially described by Reeves in a 7-month-old baby with absence of the septum pellucidum and optic nerve abnormalities (6). The condition is defined loosely by any combination of the triad of optic nerve hypoplasia $(\mathrm{ONH})$, midline neuroradiological abnormalities (such as agenesis of the corpus callosum and absence of the septum pellucidum) and pituitary hypoplasia with consequent panhypopituitarism (5-9). The reported incidence of SOD is 1/10 000 live births (10), and it is thought to be equally prevalent in males and females. Although the condition is generally sporadic, familial cases have been described.

The phenotype is highly variable, and a diagnosis of SOD usually made if two or more of the triad of $\mathrm{ONH}$, hypopituitarism or midline brain defects are present. According to Morishima \& Aranoff (11), 30\% of SOD cases have complete manifestations, $62 \%$ have the complication of hypopituitarism and $60 \%$ have an absent septum pellucidum. The condition is thought to be more frequent in children born to younger mothers (mean maternal age 22 years) $(8,12)$, although this has been disputed (13), and in some studies, there is a preponderance of primigravida mothers $(13,14)$. Recently, cases of both isolated ONH and SOD have been shown to cluster in high population density, inner city areas with high rates of unemployment and teenage pregnancy (10).

It is believed that the condition is due to a developmental insult that would have to occur during the critical period of morphogenesis for these structures, corresponding to between 4 and 6 weeks of gestation in humans. Several aetiologies have been postulated to account for the sporadic occurrence of SOD, such as viral infections, environmental teratogens and vascular or degenerative damage $(15,16)$. However, the precise aetiology of the condition remains unknown and is most likely to be multifactorial, with a combination of genetic and environmental factors. Familial cases of SOD are rare, but implicate a genetic defect underlying the developmental mechanisms involved, and are more frequently associated with an autosomal recessive manner of inheritance (17-19) although dominant inheritance has also been reported (12, 20-22).

The first gene to be implicated in SOD is HESX1, a member of the paired-like class of homeobox genes (23) which functions as a transcriptional repressor, with repression domains within the N-terminal region and the DNA-binding homeodomain $(24,25)$. It is one of the earliest markers of murine pituitary development, being initially expressed during gastrulation in a region fated to form the forebrain, and then being restricted to the ventral diencephalon by embryonic day (E) 9.0, and also in the thickened layer of oral ectoderm that will give rise to Rathke's pouch, the primordium of the anterior pituitary. Hes $x 1$ continues to be expressed in the developing anterior pituitary until E12, when expression is attenuated corresponding to progressive pituitary cell differentiation, finally becoming undetectable by E13.5.

Homozygous disruption of Hes $x 1$ in mice is associated with a phenotype closely resembling that of SOD. Abnormalities are fully penetrant, although variable, in Hes $x 1$ null mice and features include a reduction in prospective forebrain tissue, absence of developing optic vesicles, markedly decreased head size, craniofacial dysplasia with a short nose, severely reduced forebrains with no sign of telencephalic vesicle or infundibulum development, absence of olfactory placodes, hypothalamic abnormalities and aberrant morphogenesis of Rathke's pouch (26). Further analysis of neonatal and adult mutants revealed hypoplastic nasal cavities, hypoplastic olfactory bulbs, microphthalmia and anophthalmia, with abnormalities of the septum pellucidum and corpus callosum. A more detailed analysis of the Hesx1-null mutants revealed that a proportion of mice $(5 \%)$ exhibited a more severe phenotype in which no anterior pituitary gland was formed, although thickening of the oral ectoderm was detected (24). The majority of these mice showed 
multiple invaginations of the oral ectoderm, and aberrant morphogenesis of Rathke's pouch, which displayed abnormal bifurcations resulting in the apparent formation of multiple pituitary glands.

In light of the similarity between the phenotype of Hes $x 1$ null mice and SOD, we investigated the role of the human homologue of HESX1 (OMIM 601802) in patients with SOD. A homozygous missense mutation (R160C) in the homeobox of HESX1 was initially identified in a highly consanguineous family, in which two affected siblings presented with optic nerve hypoplasia, hypoplastic corpus callosum and hypoplasia of the anterior pituitary gland with an undescended/ectopic posterior pituitary and consequent panhypopituitarism $(17,26)$. This substitution leads to a loss of DNA binding. The parents were heterozygous for the mutation and phenotypically normal, consistent with an autosomal recessive mode of inheritance. Four additional homozygous mutations have subsequently been identified (Table 1), with phenotypes ranging from evolving hypopituitarism in the absence of midline and eye defects through SOD and pituitary aplasia $(27,28)$. To date, reports of screening patients with sporadic SOD have yielded eight novel heterozygous mutations within HESX1 (Table 2). These heterozygous mutations are generally associated with milder phenotypes when compared with the homozygous mutations, leading to growth hormone deficiency (GHD) with or without an undescended posterior pituitary (20), although optic nerve hypoplasia as well as midline forebrain abnormalities may be associated (21). The penetrance may be variable, and the presence of a mutation is not always associated with a phenotype. We have now screened over 800 patients with SOD and hypopituitarism, and identified mutations in $<1 \%$ of individuals confirming the rarity of HESX1 mutations (12). As a result of this screening, we have identified a number of sequence variants, including a change of unknown functional importance in a highly conserved base in a known cis-regulatory region upstream of HESX1. Whether these variants contribute to the pathogenesis remains to be proven. The overall frequency of HESX1 mutations is low, suggesting that mutations in other known or unknown genes contribute to this complex disorder, together with a likely contribution from environmental factors $(10,29)$.

\section{SOX3}

SOX 3 (OMIM 313430) is a member of the SOX (SRYrelated high mobility group (HMG) box) family of transcription factors, which were initially identified based on homology to the conserved binding motif of the HMG class, present in the mammalian sexdetermining gene, SRY (30). Approximately 20 different SOX genes have been identified in mammals, and variation in homology exhibited within the HMG box between different members allows them to be grouped into different subfamilies (31). SOX 3 was among the first of the $S O X$ genes to be cloned, and together with SOX1 and SOX2, belongs to the SOXB1 subfamily exhibiting the highest degree of similarity to SRY (30). SOX3 is encoded by a single exon producing a transcript with a coding region of $\sim 1.3 \mathrm{~kb}$, mapping to chromosome Xq27. The SOX3 protein consists of a short 66 amino acid N-terminal domain of unknown function, a 79 amino acid DNA-binding HMG domain and a longer C-terminal domain, containing four polyalanine

Table 2 Reported mutations in HESX1.

\begin{tabular}{|c|c|c|c|c|}
\hline Mutation & Inheritance & Endocrine phenotype & Neuroradiological findings & Reference \\
\hline Q6H & Dominant & GH, TSH, LH, FSH deficiency & AP hypoplasia, ectopic PP & (20) \\
\hline I26T & Recessive & $\begin{array}{l}\text { GH, LH, FSH deficiency; evolving ACTH, } \\
\text { TSH deficiency }\end{array}$ & AP hypoplasia, ectopic PP, normal ON & $(113)$ \\
\hline c.306_307insAG & Dominant & GH, LH, FSH deficiency; hypothyroidism & AP hypoplasia, ON hypoplasia & (22) \\
\hline Q117P & Dominant & GH, TSH, ACTH, LH, FSH deficiency & AP hypoplasia, ectopic PP & (114) \\
\hline c. $357+2 \mathrm{~T}>\mathrm{C}$ & Recessive & $\mathrm{GH}, \mathrm{TSH}, \mathrm{ACTH}, \mathrm{PRL}$ deficiency & AP aplasia, normal PP, normal ON & $(28)$ \\
\hline Alu insertion (exon 3) & Recessive & Panhypopituitarism & $\begin{array}{l}\text { AP aplasia, hypoplastic sella, normal PP } \\
\text { and infundibulum }\end{array}$ & (27) \\
\hline E149K & Dominant & GH deficiency & $\begin{array}{l}\text { AP hypoplasia, ectopic PP, infundibular } \\
\text { hypoplasia }\end{array}$ & $(12)$ \\
\hline c.449_450delCA & Recessive & $\mathrm{GH}, \mathrm{TSH}, \mathrm{ACTH}$ deficiency & $\begin{array}{l}\text { AP aplasia, normal PP, normal ON, thin } \\
\text { CC, hydrocephalus }\end{array}$ & (28) \\
\hline $\mathrm{R} 160 \mathrm{C}$ & Recessive & $\mathrm{GH}, \mathrm{TSH}, \mathrm{ACTH}, \mathrm{LH}, \mathrm{FSH}$ deficiency & $\begin{array}{l}\text { AP hypoplasia, ectopic PP, ON hypopla- } \\
\text { sia, ACC }\end{array}$ & $(26)$ \\
\hline S170L & Dominant & GH deficiency & $\begin{array}{l}\text { Normal AP, ON hypoplasia, ectopic PP, } \\
\text { partial ACC }\end{array}$ & (20) \\
\hline K176T & Dominant & $\begin{array}{l}\text { GH deficiency, evolving ACTH, TSH } \\
\text { deficiency }\end{array}$ & Ectopic PP & $(114)$ \\
\hline g.1684delG & Dominant & GH deficiency & $\begin{array}{l}\text { AP hypoplasia, ON hypoplasia, ACC, } \\
\text { absent PP bright spot }\end{array}$ & (21) \\
\hline T181A & Dominant & GH deficiency & $\begin{array}{l}\text { AP hypoplasia, normal ON, absent PP } \\
\text { bright spot }\end{array}$ & (20) \\
\hline
\end{tabular}

AP, anterior pituitary; PP, posterior pituitary; ON, optic nerve; (A)CC, (agenesis of the) corpus callosum. 
stretches, shown to be involved in transcriptional activation $(30,32)$.

Members of the SOXB1 subfamily of genes are expressed throughout the developing central nervous system (CNS) and are some of the earliest neural markers that are believed to play a role in neuronal determination (33). High levels of expression have also been noted in the ventral diencephalon, including the infundibulum and presumptive hypothalamus (34). Targeted disruption of Sox 3 in mice results in mutants that have a variable and complex phenotype, including craniofacial abnormalities, midline CNS defects and a reduction in size and fertility $(34,35)$. Sox 3 mutant mice of both sexes are born with expected frequency, showing no evidence for embryonic lethality, and approximately one-third of mutant mice are viable and fertile with no gross abnormalities. Heterozygous females are mosaic with respect to the mutation due to $\mathrm{X}$ inactivation and generally appear normal, although some display a mild craniofacial phenotype. However, $\sim 43 \%$ of Sox 3 null mice do not survive to weaning, and the most severely affected mice exhibit profound growth insufficiency and general weakness with craniofacial defects including overgrowth and misalignment of the front teeth and abnormality of the shape of the pinna, which was completely absent in some animals (34).

The mutants had a variable endocrine deficit, the extent of which was correlated with body weight. Pituitary levels of growth hormone $(\mathrm{GH})$, luteinizing hormone (LH), follicle-stimulating hormone (FSH) and thyrotrophin (TSH) were all lower in mutant mice when compared with wild-type mice at 2 months of age (34). Histological analysis of the pituitary gland at this stage revealed a hypoplastic anterior lobe with the presence of an additional abnormal cleft disrupting the boundary between the anterior and intermediate lobes. Further examination of Sox 3 mutant embryos revealed that Rathke's pouch displayed an abnormally expanded and bifurcated appearance in mutant embryos, which possibly results in the additional cleft observed at later stages of development and in the adult pituitary. Sox 3 is not expressed in Rathke's pouch; however, it is expressed at high levels in the ventral diencephalon including the infundibulum, which provides necessary inductive signals for the formation of the anterior pituitary (4). In Sox 3 mutants, the evagination of the infundibulum was less pronounced than observed in wild-type mice and the presumptive hypothalamus thinner and shorter (34). This suggests that the hypopituitary phenotype observed in mutant mice arises as a secondary consequence of the absence of Sox 3 in the ventral diencephalon.

In humans, tandem duplications involving chromosome Xq26-27 have been identified in several pedigrees with mental retardation and hypopituitarism (36-39). Using array comparative genomic hybridization, Solomon et al. (39) defined a critical duplication region of 3.9 Mb between Xq26.1 and Xq27.3 containing 18 annotated transcripts including SOX3. The phenotypes of affected males with X-linked hypopituitarism involving duplications within this region are variable. All affected males manifest GH deficiency and varying degrees of developmental delay or mental retardation. Some individuals have been reported to have varying combinations of deficiencies of other hormones including adrenocorticotrophin (ACTH), TSH or gonadotrophins, and complete panhypopituitarism has been documented in some cases. Unaffected carrier females in these pedigrees show preferential inactivation of the duplicated X chromosome; however, a rare family with five affected females presenting with short stature secondary to hypopituitarism, speech and language problems, hearing impairment and facial dysmorphism has also been reported with a $7.5 \mathrm{Mb}$ duplication of chromosome Xq26.2-q27.1 (40). The authors suggested that the duplication may disrupt SOX3 resulting in hemizygosity in affected females, although this was not confirmed at the molecular level. Woods et al. (41) described a pedigree with two half brothers manifesting evidence of X-linked hypopituitarism, in the absence of developmental delay, and harbouring a submicroscopic duplication on chromosome Xq27.1, further refining the critical interval to $\sim 690 \mathrm{~kb}$. The first child manifested GHD and borderline low FT4 concentrations, with hypoplasia of the lower half of the infundibulum and an abnormal corpus callosum, which contained a cyst within the splenium. The second sibling manifested a more severe phenotype of combined pituitary hormone deficiency (CPHD), with complete absence of the infundibulum and hypoplastic genitalia; however, his corpus callosum appeared normal. Both patients had anterior pituitary hypoplasia and an undescended posterior pituitary as revealed by magnetic resonance imaging (MRI). The duplication identified in this family is the smallest described to date encompassing $S_{O X} 3$ and two additional transcripts of unknown function, neither of which is expressed in the developing infundibulum (41), suggesting that the phenotype in these patients is due to the presence of an additional copy of SOX3.

Further implication of SOX 3 in X-linked hypopituitarism comes from the identification of patients harbouring an expansion of one of the polyalanine tracts within the gene $(41,42)$. Laumonnier et al. (42) identified an in-frame duplication of $33 \mathrm{bp}$ occurring between nucleotides 711 and 743 and co-segregating in affected males in a large family with X-linked mental retardation and GH deficiency. This mutation encodes an additional 11 alanine residues and is predicted to cause expansion of the normal polyalanine tract from 15 to 26 residues. Additionally, a second novel expansion of seven alanine residues within the same tract has been identified in three siblings of a consanguineous pedigree presenting with profound and complete panhypopituitarism in association with anterior pituitary hypoplasia, an absent or hypoplastic infundibulum and an 
undescended posterior pituitary. There was no evidence of mental retardation or craniofacial dysmorphism in these individuals.

In vitro analysis of the $S O X 3+7$ alanine expansion identified by Woods et al. (2005) revealed that the expansion leads to partial loss of function possibly due to impairment of nuclear localization, as the mutant protein was largely excluded from the nucleus when compared with wild-type SOX3 which is predominantly localized within the nucleus of the cell (41). Similar findings have also been shown for the mutant SOX3 protein containing the +11 alanine expansion, which forms aggregates within the cytoplasm (43).

In summary, both duplications of Xq27 encompassing SOX3 and loss-of-function polyalanine expansion mutations are essentially associated with similar phenotypes, predominantly infundibular hypoplasia, suggesting that gene dosage of $\mathrm{SOX} 3$ is critical for normal development of the diencephalon and infundibulum, and consequently the anterior pituitary.

\section{SOX2}

SOX2 (OMIM 184429) is also a member of the same SOXB1 subfamily as SOX3 and SOX1 (OMIM 602148). In the mouse, initial expression of Sox 2 is detected at $2.5 \mathrm{dpc}$ at the morula stage, and then in the inner cell mass of the blastocyst at $3.5 \mathrm{dpc}$. Later expression of Sox2, following gastrulation, is restricted to the presumptive neuroectoderm, and by $9.5 \mathrm{dpc}$, it is expressed throughout the brain, CNS, sensory placodes, branchial arches, gut endoderm and the oesophagus and trachea $(44,45)$. Homozygous loss of Sox 2 results in peri-implantation lethality, whereas Sox2 heterozygous mice appear relatively normal but show a reduction in size and male fertility (46). Further studies that have resulted in the reduction of Sox 2 expression levels below $40 \%$ when compared with the normal levels result in anophthalmia in the affected mutants (47).

Given the observation of growth retardation and reduced fertility, we have recently investigated the role of Sox 2 in murine pituitary development, showing that a proportion of heterozygous animals manifested a variable hypopituitary phenotype, with hypoplasia and abnormal morphology of the anterior pituitary gland with concomitant reduction in levels of GH, LH, ACTH and TSH (48). Similar to its murine counterpart, the human SOX2 gene is composed of a single exon encoding a 317 amino acid protein containing an N-terminal domain of unknown function, a DNAbinding HMG domain and a C-terminal transcriptional activation domain. Twelve heterozygous de novo mutations in SOX2 were previously reported in 14 human patients associated with bilateral anophthalmia or severe microphthalmia with additional abnormalities including developmental delay, learning difficulties, oesophageal atresia and genital abnormalities (45,
49-52). All of these mutations occurred de novo and included five nonsense, four frameshift, one deletion and two missense mutations. We have subsequently reported six patients harbouring de novo heterozygous mutations in SOX2, resulting in loss of function of the mutant protein, four of whom were previously unreported (c.60insG, c.387delC, Y160X and c.479delA). Clinical evaluation revealed that in addition to anophthalmia/microphthalmia, SOX2 mutations were also associated with anterior pituitary hypoplasia and hypogonadotrophic hypogonadism, which resulted in the absence of puberty in all six patients and genital abnormalities in males. All affected individuals exhibited learning difficulties with other variable manifestations including hippocampal abnormalities, defects of the corpus callosum, oesophageal atresia and sensorineural hearing loss (48). The mutations were associated with significant loss of function that included loss of DNA binding, nuclear localization and transcriptional activation, suggesting that these phenotypes arise as a result of haploinsufficiency of SOX2 in development. More recently, Sato et al. (53) have reported an additional patient with a missense mutation in the HMG domain (L75Q), resulting in decreased DNAbinding affinity of the mutant protein. The affected individual manifested unilateral right-sided anophthalmia and isolated hypogonadotrophic hypogonadism, with a normal anterior pituitary and normal mental development, further supporting a critical role for SOX2 in the regulation of correct gonadotrophin production in addition to eye development.

\section{LHX3/LHX4}

Lhx 3 is a member of the LIM family of homeobox genes that are characterized by the presence of a unique cysteine/histidine-rich zinc-binding LIM domain. The protein contains two such tandemly repeated LIM motifs between the N-terminus and the homeodomain, which are likely to be involved in protein-protein interactions $(54,55) . L h \times 3$ is one of the earliest transcription factors expressed within the developing pituitary, initially detectable with strong uniform expression in Rathke's pouch. Expression is maintained in the pouch and is subsequently restricted to fields fated to form the anterior and intermediate lobes. By $16.5 \mathrm{dpc}$, the gene is expressed in all regions of the developing anterior and intermediate pituitary, but not the posterior gland, and continued expression is essential for the establishment of hormone-producing cell types. Expression persists throughout development and is also detected in the adult pituitary, suggesting a role in maintenance of one or more of the mature anterior pituitary cell types $(54,56)$. In addition to the pituitary, $L h \times 3$ is also detected transiently in regions of the developing spinal cord, prior to neural tube closure, and later within the restricted regions of the hindbrain, in addition to the cells in immediate proximity to 
the otic vesicles. Mice with a targeted homozygous disruption of $L h x 3$ die shortly after birth, although the cause of death is unknown, and exhibit pituitary aplasia, suggesting an essential role of $L h \times 3$ in differentiation and proliferation of anterior pituitary cell lineages. Although Rathke's pouch is initially formed in $L h x 3$ null mice, a failure of proliferation and growth results in a lack of the anterior and intermediate lobes of the pituitary with depletion of all hormoneproducing cell types except corticotrophs, which differentiate and express proopiomelanocortin (POMC) but fail to proliferate $(57,58)$. The posterior pituitary appeared grossly unaffected, as did the hindbrain and spinal cord, and heterozygous mice were apparently normal and fertile (57).

Homozygous mutations in LHX3 (OMIM 600577) have currently been identified in 12 patients from seven unrelated consanguineous families, all of which result in loss of LHX3 function (59-63). The patients presented with an endocrine phenotype similar to that observed in individuals with PROP1 mutations with a deficit in all anterior pituitary hormones except ACTH. This was additionally associated in 9 out of 12 patients with a short rigid, cervical spine with limited head rotation and trunk movement. As with PROP1-deficient patients, pituitary morphology is variable between patients with $L H X 3$ mutations, with two patients from one family exhibiting small anterior pituitaries with a normal posterior pituitary and midline structures on MRI. However, an additional individual from an unrelated family demonstrated a markedly enlarged anterior pituitary that was not evident in a previous MR scan performed 10 years previously (59). Additionally, Bhangoo et al. (2006) recently reported a further patient with a hypointense lesion in the anterior pituitary consistent with a microadenoma (61).

$L h \times 4$ is closely related to $L h x 3$ and is expressed in specific fields of the developing brain and spinal cord. Similar to $L h x$ 3, $L h x 4$ is initially expressed throughout the invaginating Rathke's pouch; however, subsequent expression is transient and restricted to the future anterior lobe, whereas $\operatorname{Lh} x 3$ expression is maintained throughout the whole pouch. A similar pattern of transient expression of LHX4 (OMIM 602146) in the developing pituitary and spinal cord, with continuous expression of $L H X 3$, has also been observed in human development (62). Null mutations of Lhx4 do not prevent pouch formation; however, the pouch is defective with reduced numbers of the various anterior pituitary cell types. $L h \times 3^{-/-}, L h x 4^{-/-}$double mutant mice show a more severe phenotype than either single mutant with an early arrest of pituitary development; additionally, a single normal copy of either $L h x 3$ or $L h x 4$ in murine development is sufficient for the formation of a definitive pouch, thereby suggesting that these two genes may act in a redundant manner during early pituitary development (64).
To date, only a single mutation within $L H X 4$ has been reported in a three-generation family, in which the mutation, which abolishes normal splicing, segregates in a dominant and fully penetrant manner. The probands presented with short stature and were found to be GH, TSH and ACTH deficient (65). Anterior pituitary hypoplasia was revealed by MRI with an ectopic posterior pituitary and absent pituitary stalk. However, other affected family members presented with short stature associated with isolated GH deficiency and a normal posterior pituitary. Additional manifestations included a poorly formed sella turcica and pointed cerebellar tonsils, suggesting that $L H X 4$ may be a factor that tightly coordinates brain development and skull shaping.

\section{TBX19}

TBX19 (OMIM 604614; also referred to as TPIT) is a member of the T-box family of transcription factors that contain a homologous DNA-binding domain (the T-box) first identified in the mouse Brachyury $(T)$ gene. Tbx 19 is not expressed within Rathke's pouch, but by $11.5 \mathrm{dpc}$, expression appears within the developing anterior pituitary gland, as well as a region of the ventral diencephalon. Later expression in the developing and adult murine pituitary is detected in only two cell types, the POMC (OMIM 176830)-expressing corticotrophs in the anterior lobe and melanotrophs forming the intermediate lobe. It is essential for cell-specific expression of the POMC gene and terminal differentiation of the pituitary corticotroph lineage (66-68).

Consistent with the exclusive expression in pituitary POMC cells, mutations in TBX19 are associated at high frequency with neonatal isolated ACTH deficiency, but never in cases of juvenile-onset deficiency. Twelve independent mutations have been identified, including nonsense, missense, frameshift and splicing mutations in addition to a large genomic deletion of $5.2 \mathrm{~kb}$ encompassing exons 2 and 3 of the gene (69-72). All of these mutations have been shown or are predicted to result in loss of TBX19 function, and all patients appear to be homozygous or compound heterozygous for TBX19 mutations, with unaffected heterozygous parents, implying a recessive mode of inheritance. Vallette-Kasic et al. have reported the largest series to date and demonstrated TBX19 mutations in 17 out of 27 patients from 21 unrelated families, suggesting that mutations in the gene are the principal molecular cause of congenital neonatal isolated ACTH deficiency. Moreover, three patients were identified to carry only one mutant TBX19 allele, although family history implied recessive inheritance, suggesting that additional, as yet unidentified, mutations may be present in the regulatory regions of the gene in some cases (70). Patients with TBX19 mutations present with a homogeneous clinical phenotype with an endocrine profile consisting of very low basal plasma ACTH and cortisol levels, with no 
significant ACTH response to corticotrophin-releasing hormone; however, plasma cortisol levels may respond to repeated ACTH administration, with normal function of all other pituitary axes. Severe hypoglycaemia, associated with seizures in some cases, and prolonged cholestatic jaundice are classically associated with ACTH deficiency presenting in the neonatal period (70). Furthermore, Vallette-Kasic et al. noted that in their series, about $25 \%$ of families with segregating TBX19 mutations (5 out of 21) suffered a neonatal death, suggesting that isolated ACTH deficiency may be an underestimated cause of neonatal death. Tbx19 null mice constitute a model of isolated ACTH deficiency similar to the phenotype observed in human patients with TBX19 mutations (69).

\section{PROP1}

Prop1 is a paired-like homeodomain transcription factor, expressed exclusively within the embryonic pituitary. Expression is first detected in the dorsal portion of the murine Rathke's pouch in a region overlapping the expression domain of Hesx 1 . Maximal expression of Prop1 is achieved at $12 \mathrm{dpc}$ in the full caudomedial area of the developing anterior pituitary followed by a marked decrease, becoming undetectable by $15.5 \mathrm{dpc}(73)$. The Ames dwarf $(d f)$ mouse harbours a naturally occurring serine to proline (S83P) substitution within the homeodomain of Prop1, resulting in a mutant protein with an eightfold lower DNA-binding affinity than wild-type Prop1 (73). Homozygous Ames dwarf mice exhibit severe proportional dwarfism, hypothyroidism and infertility, and although early pituitary development is similar to wild-type mice, the emerging anterior pituitary gland is reduced by about $50 \%$, displaying an abnormal looping appearance (74). The adult Ames dwarf mouse exhibits GH, TSH and prolactin (PRL) deficiency resulting from a severe reduction of somatotroph, lactotroph and caudomedial thyrotroph lineages with $\sim 1 \%$ of the normal complement of each cell type. Additionally, these mice have reduced gonadotrophin expression correlating with low LH and FSH plasma levels (73-75).

Following the identification of Prop1 as the gene underlying the Ames dwarf phenotype in mice, Wu et al. (76) reported the first mutations in PROP1 (OMIM 601538) in human patients with GH, TSH and PRL deficiency in addition to reduced gonadotrophins and a failure to enter puberty spontaneously. To date, 22 distinct mutations have been identified in more than 170 patients, suggesting that $P R O P 1$ mutations are the most common cause of CPHD reported, accounting for $\sim 50 \%$ of familial cases $(77,78)$, although the incidence in sporadic cases is much lower (79). All affected individuals exhibit recessive inheritance, and, with one exception, all mutations identified to date involve the DNA-binding homeodomain, which is highly conserved between mouse and human sharing $91 \%$ identity at the nucleotide level (80). The majority of these mutations are predicted to result in complete loss of function of the protein by ablating DNA binding and transcriptional activation. However, in vitro analysis has shown that some missense mutations retain partial activity $(76,81$, $82)$. By far, the most common mutation (50-72\% of all familial PROP1 mutations) $(77,78,83)$, detected in multiple unrelated families from several different countries, is a 2 bp deletion among three tandem GA repeats $\left({ }^{296}\right.$-GAGAGAG- $\left.{ }^{302}\right)$ within exon 2 resulting in a frameshift at codon 101 and the introduction of a termination codon at position 109 (often referred to as S109X), and probably represents a mutational hot spot within the gene, rather than a single common founder mutation (84). Recently, Reynaud et al. (85) reported the first PROP1 mutation downstream of the homeodomain involving a substitution of a tryptophan residue for a stop codon at position 194 (W194X) in the transactivation domain, with the resultant mutant protein showing only $34 \%$ activity when compared with wild-type PROP1.

Recessive inheritance of mutations in PROP1 is typically associated with GH, TSH, PRL and gonadotrophin deficiencies, although the time of initiation and severity of pituitary hormone deficiencies is highly variable. Most patients present with early-onset $\mathrm{GH}$ deficiency and growth retardation; however, normal growth in early childhood has been reported in a patient who attained a normal final height without $\mathrm{GH}$ replacement therapy (86). TSH deficiency is also highly variable and has been reported as the first presenting symptom in some cases, while others show delayed TSH deficiency which may not be present at birth $(77,87-$ 89). Individuals with PROP1 mutations exhibit normal ACTH/cortisol levels in early life but often demonstrate an evolving cortisol deficiency that is strongly and significantly correlated with increasing age (89-93). However, patients as young as 6-7 years have also been described with cortisol deficiency $(93,94)$.

Although Prop1 is essential for the differentiation of gonadotrophs in foetal life, the spectrum of gonadotrophin deficiency is again extremely variable in patients with PROP1 mutations. Clinical variability can range from hypogonadism with complete lack of pubertal development to reports of spontaneous, albeit often delayed, onset of puberty with subsequent development of gonadotrophin deficiency requiring hormone replacement $(77,87,88,91)$.

The pituitary morphology in patients with PROP1 mutations is also highly variable; most individual reports have documented a normal pituitary stalk and posterior lobe, with a small or normal size anterior pituitary gland on MRI. However, in some cases, an enlarged anterior pituitary gland has been reported $(76$, $89,95)$. Longitudinal analyses of anterior pituitary size over time have revealed that a significant number of patients demonstrated pituitary enlargement in early childhood with subsequent regression and involution; 
thus, ensuing MRI in older patients usually demonstrates anterior pituitary hypoplasia $(92,96)$. The pituitary enlargement consists of a mass lesion interposed between the anterior and posterior lobes, possibly originating from the intermediate lobe (96). Turton et al. (2005) recently demonstrated that the mass can wax and wane in size prior to eventual involution (79). To date, the underlying mechanism for the mass remains unknown. There has been only one report of a biopsy of the 'tumour', and the histology was non-specific with the presence of amorphous material with no signs of apoptosis and no recognizable cell lines $(97,98)$. Consequent to the highly variable phenotype associated with PROP1 mutations, no genotypephenotype correlation has been identified; furthermore, phenotypic differences have been reported in siblings with identical mutations (87). The evolving nature of hormone insufficiencies in patients with PROP1 mutations suggests a progressive decline in the anterior pituitary axis, indicating a need for continual monitoring of patients for the development of hormone insufficiencies that may not be apparent at initial presentation.

\section{POU1F1}

POU1F1 (OMIM 173110; previously known as PIT1) is a pituitary-specific transcription factor belonging to the POU homeodomain family of transcription factors (named after the genes PIT1, OCT1 and unc-86) characterized by a highly conserved DNA-binding domain consisting of a POU-specific domain and a POU homeodomain. In the mouse, Pou1f1 is expressed relatively late during pituitary development $(14.5 \mathrm{dpc})$, and expression persists throughout post-natal life and adulthood, restricted to the anterior pituitary lobe (99). Pou1f1 is essential for the development of somatotroph, lactotroph and thyrotroph cell lineages in the anterior pituitary (100), and for the subsequent expression of the GH-1 (OMIM 139250), PRL (OMIM 176760) and TSH- $\beta$ (OMIM 188540) genes between 15.5 and $17 \mathrm{dpc}$ (101). Two naturally occurring murine models have shed light on the role of Pou1f1 in normal pituitary development. In the Snell dwarf $(d w)$ mouse, a recessive point mutation (W261C) results in the absence of somatotrophs, lactotrophs and thyrotrophs (102). A similar phenotype results in the Jackson dwarf mouse $(d w J)$ that harbours a recessive null mutation due to rearrangement of Pou1f1. Pou1f1-binding sites have also been found in the GHRHR (OMIM 139191) and the Pou1f1 gene itself $(100,103)$, and autoregulation is required to sustain gene expression once the Pou1f1 protein has reached a critical threshold (104).

The first mutation within POUIFI was identified by Tatsumi et al. (1992) in a child with GH, PRL and profound TSH deficiency caused by homozygosity for a nonsense mutation within the gene (105). The majority of mutations identified in POU1F1 to date are recessive; however, in addition, a number of heterozygous point mutations have been reported (106). Of these, the amino acid substitution R271W appears to be a 'hot spot' for POU1F1 mutations (106) and has been identified in several unrelated patients of different ethnic backgrounds. When co-transfected with wild-type POU1F1, this mutant protein prevented transcriptional activation by the wild-type protein acting as a dominant negative (107), although this has been recently disputed (108).

The spectrum of hormone deficiency can vary in patients with POU1F1 mutations; GH and PRL deficiencies generally present early in life; however, TSH deficiency can be highly variable with presentation later in childhood $(109,110)$. We have recently described a POU1F1 mutation in a 21-year-old patient with GH and PRL deficiency who has normal thyroid function to date (111). Magnetic resonance imaging demonstrates a small or normal anterior pituitary with a normal posterior pituitary and infundibulum, and no midline abnormalities. Since the first report, a total of 27 POU1F1 mutations have been described including 22 recessive and 5 dominant mutations in over 60 patients originating from 19 different countries, all of which have been associated with a broadly similar phenotype of GH, TSH and PRL deficiency (112).

\section{Conclusions}

Over the past decade, there has been an explosion in the knowledge of the genetic cascade that orchestrates hypothalamo-pituitary development. Several transcription factors and signalling molecules are critical for cell differentiation and proliferation at a very early stage of gestation. The mouse has served as an excellent model for understanding the genetic basis of congenital hypopituitarism in humans, although the correlation between mouse and human disease phenotypes is variable. This candidate gene approach, based on mouse studies, had led to the identification of several human mutations that disrupt hypothalamo-pituitary development resulting in specific patterns of hormone dysfunction.

Establishing the genotype can aid the management of individual patients with hypopituitarism. For example, a patient with an identified PROP1 mutation exhibiting an enlarged anterior pituitary may be at risk of visual impairment due to anterior pituitary hyperplasia; however, a number of reports in individuals with PROP1 mutations have shown the enlarged anterior pituitary to undergo spontaneous involution. Careful monitoring of the anterior pituitary in such cases may prevent the patient undergoing further invasive procedures. Additionally, identification of a mutation within POU1F1 predicts that cortisol and gonadotrophin secretion will remain normal in the patient. Identification of the genotype can also aid in genetic 
counselling and early diagnosis, particularly in autosomal dominant POU1F1 mutations.

However, no genetic aetiology has been established to date in most patients with hypopituitarism. Given that a number of these patients may represent familial cases, it is clear that many genes implicated in hypopituitarism remain to be identified. Mapping and identification of the underlying causative mutations in these rare familial cases will help to identify novel genes for mutational screening in the more common sporadic forms of the condition. Additionally, naturally occurring and genetically engineered mouse models of hypopituitary phenotypes have proved to be extremely fruitful in the past in identifying genes involved in pituitary development in humans. The identification and characterization of novel genes, together with their downstream targets and interacting partners, will in future enable a greater understanding of the disorder, in addition to unravelling the processes inherent in the normal development of the pituitary gland.

\section{Acknowledgement}

We would like to thank all the patients and their families who participated in these studies. This work was supported by the Medical Research Council UK (MTD, DK). Research at the Institute of Child Health and Great Ormond Street Hospital for Children NHS Trust benefits from research-and-development funding from the NHS executive.

\section{Disclosure}

This paper forms part of a European Journal of Endocrinology supplement, supported by Ipsen. The authors disclose: D. Kelberman: no interaction with Ipsen. M. Dattani: member of Genentech and Ipsen Network Advisory Board, has received consultation fees from Ipsen.

This article was subject to rigorous peer review before acceptance and publication.

\section{References}

1 Takuma N, Sheng HZ, Furuta Y, Ward JM, Sharma K, Hogan LM, Pfaff SL, Westphal H, Kimura S \& Mahon KA. Formation of Rathke's pouch requires dual induction from the diencephalon. Development 1998 125/23 4840.

2 Dasen JS \& Rosenfeld MG. Signaling mechanisms in pituitary morphogenesis and cell fate determination. Current Opinion in Cell Biology 199911 669-677.

3 Dasen JS \& Rosenfeld MG. Signaling and transcriptional mechanisms in pituitary development. Annual Review of Neuroscience 200124 327-355.

4 Rizzoti K \& Lovell-Badge R. Early development of the pituitary gland: induction and shaping of Rathke's pouch. Reviews in Endocrine and Metabolic Disorders 20056 161-172.
5 de Morsier G. Studies in cranio-encephalic dysraphia. I. Agenesia of the olfactory lobe (lateral telencephaloschisis) and of the callous and anterior commissures (median telencephaloschisis); olfacto-genital dysplasia. Schweizer Archiv Für Neurologie und Psychiatrie $1954 \mathbf{7 4}$ 309-361.

6 Reeves DL. Congenital absence of the septum pellucidum. Bulletin of the Johns Hopkins Hospital 194169 61-71.

7 Hoyt WF, Kaplan SL, Grumbach MM \& Glaser JS. Septo-optic dysplasia and pituitary dwarfism. Lancet 19701 893-894.

8 Arslanian SA, Rothfus WE, Foley TP Jr \& Becker DJ. Hormonal, metabolic, and neuroradiologic abnormalities associated with septo-optic dysplasia. Acta Endocrinologica 1984107 282-288.

9 Stanhope R, Preece MA \& Brook CG. Hypoplastic optic nerves and pituitary dysfunction. A spectrum of anatomical and endocrine abnormalities. Archives of Disease in Childhood 198459 111-114.

10 Patel L, McNally RJ, Harrison E, Lloyd IC \& Clayton PE. Geographical distribution of optic nerve hypoplasia and septooptic dysplasia in Northwest England. Journal of Pediatrics 2006 148 85-88.

11 Morishima A \& Aranoff GS. Syndrome of septo-optic-pituitary dysplasia: the clinical spectrum. Brain and Development $1986 \mathbf{8}$ 233-239.

12 McNay DE, Turton JP, Kelberman D, Woods KS, Brauner R, Papadimitriou A, Keller E, Keller A, Haufs N, Krude H, Shalet SM \& Dattani MT. HESX1 mutations are an uncommon cause of septooptic dysplasia and hypopituitarism. Journal of Clinical Endocrinology and Metabolism 200792 691-697.

13 Acers TE. Optic nerve hypoplasia: septo-optic-pituitary dysplasia syndrome. Transactions of the American Ophthalmological Society $198179425-457$.

14 Izenberg N, Rosenblum M \& Parks JS. The endocrine spectrum of septo-optic dysplasia. Clinical Pediatrics 198423 632-636.

15 Roessmann U, Velasco ME, Small EJ \& Hori A. Neuropathology of 'septo-optic dysplasia' (de Morsier syndrome) with immunohistochemical studies of the hypothalamus and pituitary gland. Journal of Neuropathology and Experimental Neurology 198746 597-608.

16 Zaias B \& Becker D. Septo-optic dysplasia: developmental or acquired abnormality? A case report Transactions of the American Neurological Association 1978103 273-277.

17 Wales JK \& Quarrell OW. Evidence for possible Mendelian inheritance of septo-optic dysplasia. Acta Paediatrica 199685 391-392.

18 Blethen SL \& Weldon VV. Hypopituitarism and septo-optic 'dysplasia' in first cousins. American Journal of Medical Genetics 198521 123-129.

19 Benner JD, Preslan MW, Gratz E, Joslyn J, Schwartz M \& Kelman S. Septo-optic dysplasia in two siblings. American Journal of Ophthalmology 1990 109 632-637.

20 Thomas PQ, Dattani MT, Brickman JM, McNay D, Warne G, Zacharin M, Cameron F, Hurst J, Woods K, Dunger D, Stanhope R, Forrest S, Robinson IC \& Beddington RS. Heterozygous HESX1 mutations associated with isolated congenital pituitary hypoplasia and septo-optic dysplasia. Human Molecular Genetics 200110 $39-45$.

21 Cohen RN, Cohen LE, Botero D, Yu C, Sagar A, Jurkiewicz M \& Radovick S. Enhanced repression by HESX1 as a cause of hypopituitarism and septooptic dysplasia. Journal of Clinical Endocrinology and Metabolism $2003 \mathbf{8 8} 4832-4839$.

22 Tajima T, Hattorri T, Nakajima T, Okuhara K, Sato K, Abe S, Nakae J \& Fujieda K. Sporadic heterozygous frameshift mutation of HESX1 causing pituitary and optic nerve hypoplasia and combined pituitary hormone deficiency in a Japanese patient. Journal of Clinical Endocrinology and Metabolism 200388 45-50.

23 Thomas PQ, Johnson BV, Rathjen J \& Rathjen PD. Sequence, genomic organization, and expression of the novel homeobox gene Hesx1. Journal of Biological Chemistry $1995 \mathbf{2 7 0}$ 3869-3875.

24 Dasen JS, Barbera JP, Herman TS, Connell SO, Olson L, Ju B, Tollkuhn J, Baek SH, Rose DW \& Rosenfeld MG. Temporal 
regulation of a paired-like homeodomain repressor/TLE corepressor complex and a related activator is required for pituitary organogenesis. Genes and Development 200115 3193-3207.

25 Brickman JM, Clements M, Tyrell R, McNay D, Woods K, Warner J, Stewart A, Beddington RS \& Dattani M. Molecular effects of novel mutations in Hesx1/HESX1 associated with human pituitary disorders. Development 2001128 5189-5199.

26 Dattani MT, Martinez-Barbera JP, Thomas PQ, Brickman JM, Gupta R, Martensson IL, Toresson H, Fox M, Wales JKH, Hindmarsh PC, Krauss S, Beddington RSP \& Robinson ICAF. Mutations in the homeobox gene HESX1/Hes 1 associated with septo-optic dysplasia in human and mouse. Nature Genetics 1998 19 125-133.

27 Sobrier ML, Netchine I, Heinrichs C, Thibaud N, Vie-Luton MP, Van VG \& Amselem S. Alu-element insertion in the homeodomain of HESX1 and aplasia of the anterior pituitary. Human Mutation 200525503.

28 Sobrier ML, Maghnie M, Vie-Luton MP, Secco A, di IN, Lorini R \& Amselem S. Novel HESX1 mutations associated with a lifethreatening neonatal phenotype, pituitary aplasia, but normally located posterior pituitary and no optic nerve abnormalities. Journal of Clinical Endocrinology and Metabolism 200691 4528-4536.

29 Tornqvist K, Ericsson A \& Kallen B. Optic nerve hypoplasia: risk factors and epidemiology. Acta Ophthalmologica Scandinavica 2002 80 300-304.

30 Stevanovic M, Lovellbadge R, Collignon J \& Goodfellow PN. Sox3 is an X-linked gene-related to Sry. Human Molecular Genetics 1993 2 2013-2018.

31 Pevny LH \& Lovell-Badge R. Sox genes find their feet. Current Opinion in Genetics and Development 19977 338-344.

32 Kamachi Y, Uchikawa M, Collignon J, Lovell-Badge R \& Kondoh $\mathrm{H}$. Involvement of Sox 1,2 and 3 in the early and subsequent molecular events of lens induction. Development $19981252521-2532$.

33 Pevny L \& Placzek M. SOX genes and neural progenitor identity. Current Opinion in Neurobiology 200515 7-13.

34 Rizzoti K, Brunelli S, Carmignac D, Thomas PQ, Robinson IC \& Lovell-Badge R. SOX 3 is required during the formation of the hypothalamo-pituitary axis. Nature Genetics 200436 247-255.

35 Weiss J, Meeks JJ, Hurley L, Raverot G, Frassetto A \& Jameson JL. So 3 is required for gonadal function, but not sex determination, in males and females. Molecular and Cellular Biology 200323 8084-8091.

36 Hamel BC, Smits AP, Otten BJ, van den HB, Ropers HH \& Mariman EC. Familial X-linked mental retardation and isolated growth hormone deficiency: clinical and molecular findings. American Journal of Medical Genetics 199664 35-41.

37 Lagerstrom-Fermer M, Sundvall M, Johnsen E, Warne GL, Forrest SM, Zajac JD, Rickards A, Ravine D, Landegren U \& Pettersson U. X-linked recessive panhypopituitarism associated with a regional duplication in Xq25-q26. American Journal of Human Genetics 199760 910-916.

38 Hol FA, Schepens MT, van Beersum SE, Redolfi E, Affer M, Vezzoni P, Hamel BC, Karnes PS, Mariman EC \& Zucchi I. Identification and characterization of an Xq26-q27 duplication in a family with spina bifida and panhypopituitarism suggests the involvement of two distinct genes. Genomics 200069 174-181.

39 Solomon NM, Nouri S, Warne GL, Lagerstrom-Fermer M, Forrest SM \& Thomas PQ. Increased gene dosage at Xq26-q27 is associated with X-linked hypopituitarism. Genomics 200279 553-559.

40 Stankiewicz P, Thiele H, Schlicker M, Cseke-Friedrich A, BartelFriedrich S, Yatsenko SA, Lupski JR \& Hansmann I. Duplication of Xq26.2-q27.1, including SOX3, in a mother and daughter with short stature and dyslalia. American Journal of Medical Genetics. Part A 2005 138A 11-17.

41 Woods KS, Cundall M, Turton J, Rizotti K, Mehta A, Palmer R, Wong J, Chong WK, Al Zyoud M, El Ali M, Otonkoski T, MartinezBarbera JP, Thomas PQ, Robinson IC, Lovell-Badge R,
Woodward KJ \& Dattani MT. Over- and underdosage of SOX3 is associated with infundibular hypoplasia and hypopituitarism. American Journal of Human Genetics 200576 833-849.

42 Laumonnier F, Ronce N, Hamel BCJ, Thomas P, Lespinasse J, Raynaud M, Paringaux C, Van Bokhoven H, Kalscheuer V, Fryns JP, Chelly J, Moraine C \& Briault S. Transcription factor SOX3 is involved in X-linked mental retardation with growth hormone deficiency. American Journal of Human Genetics 200271 $1450-1455$.

43 Albrecht AN, Kornak U, Boddrich A, Suring K, Robinson PN, Stiege AC, Lurz R, Stricker S, Wanker EE \& Mundlos S. A molecular pathogenesis for transcription factor associated polyalanine tract expansions. Human Molecular Genetics 200413 2351-2359.

44 Wood HB \& Episkopou V. Comparative expression of the mouse Sox1, Sox 2 and Sox 3 genes from pre-gastrulation to early somite stages. Mechanisms of Development 199986 197-201.

45 Williamson KA, Hever AM, Rainger J, Rogers RC, Magee A, Fiedler Z, Keng WT, Sharkey FH, McGill N, Hill CJ, Schneider A, Messina M, Turnpenny PD, Fantes JA, van H V \& FitzPatrick DR. Mutations in SOX2 cause anophthalmia-esophageal-genital (AEG) syndrome. Human Molecular Genetics $2006 \quad 15$ 1413-1422.

46 Avilion AA, Nicolis SK, Pevny LH, Perez L, Vivian N \& LovellBadge R. Multipotent cell lineages in early mouse development depend on SOX2 function. Genes and Development 200317 126-140.

47 Taranova OV, Magness ST, Fagan BM, Wu Y, Surzenko N, Hutton SR \& Pevny LH. SOX2 is a dose-dependent regulator of retinal neural progenitor competence. Genes and Development 200620 1187-1202.

48 Kelberman D, Rizzoti K, Avilion A, Bitner-Glindzicz M, Cianfarani S, Collins J, Chong WK, Kirk JM, Achermann JC, Ross R, Carmignac D, Lovell-Badge R, Robinson IC \& Dattani MT. Mutations within Sox2/SOX2 are associated with abnormalities in the hypothalamo-pituitary-gonadal axis in mice and humans. Journal of Clinical Investigation $20061162442-2455$.

49 Fantes J, Ragge NK, Lynch SA, Mcgill NI, Collin JRO, HowardPeebles PN, Hayward C, Vivian AJ, Williamson K, van Heyningen V \& FitzPatrick DR. Mutations in SOX2 cause anophthalmia. Nature Genetics 200333 461-463.

50 Ragge NK, Lorenz B, Schneider A, Bushby K, de Sanctis L, de Sanctis U, Salt A, Collin JRO, Vivian AJ, Free SL, Thompson P, Williamson KA, Sisodiya SM, van Heyningen V \& FitzPatrick DR. SOX2 anophthalmia syndrome. American Journal of Medical Genetics. Part A 2005 135A 1-7.

51 Hagstrom SA, Pauer GJT, Reid J, Simpson E, Crowe S, Maumenee IH \& Traboulsi EI. SOX2 mutation causes anophthalmia, hearing loss, and brain anomalies. American Journal of Medical Genetics. Part A 2005 138A 95-98.

52 Zenteno JC, Gascon-Guzman G \& Tovilla-Canales JL. Bilateral anophthalmia and brain malformations caused by a 20-bp deletion in the SOX2 gene. Clinical Genetics $200568564-566$.

53 Sato N, Kamachi Y, Kondoh H, Shima Y, Morohashi K, Horikawa R \& Ogata T. Hypogonadotropic hypogonadism in an adult female with a heterozygous hypomorphic mutation of SOX2. European Journal of Endocrinology 2007156 167-171.

54 Bach I, Rhodes SJ, Pearse RV, Heinzel T, Gloss B, Scully KM, Sawchenko PE \& Rosenfeld MG. P-Lim, a LIM homeodomain factor, is expressed during pituitary organ and cell commitment and synergizes with Pit-1. PNAS 199592 2720-2724.

55 Schmitt S, Biason-Lauber A, Betts D \& Schoenle EJ. Genomic structure, chromosomal localization, and expression pattern of the human LIM-Homeobox3 (LHX 3) gene. Biochemical and Biophysical Research Communications 2000274 49-56.

56 Zhadanov AB, Bertuzzi S, Taira M, Dawid IB \& Westphal H. Expression pattern of the murine Lim class homeobox gene $L h x 3$ in subsets of neural and neuroendocrine tissues. Developmental Dynamics 1995202 354-364. 
57 Sheng HZ, Zhadanov AB, Mosinger B, Fujii T, Bertuzzi S, Grinberg A, Lee EJ, Huang SP, Mahon KA \& Westphal H. Specification of pituitary cell lineages by the LIM homeobox gene Lhx3. Science 1996272 1004-1007.

58 Sheng HZ, Moriyama K, Yamashita T, Li H, Potter SS, Mahon KA \& Westphal H. Pituitary organogenesis controlled by LIMhomeobox genes. Developmental Biology 1997186 B132.

59 Netchine I, Sobrier ML, Krude H, Schnabel D, Maghnie M, Marcos E, Duriez B, Cacheux V, von Moers A, Goossens M, Gruters A \& Amselem S. Mutations in LHX3 result in a new syndrome revealed by combined pituitary hormone deficiency. Nature Genetics 200025 182-186.

60 Sloop KW, Parker GE, Hanna KR, Wright HA \& Rhodes SJ. LHX3 transcription factor mutations associated with combined pituitary hormone deficiency impair the activation of pituitary target genes. Gene 2001265 61-69.

61 Bhangoo AP, Hunter CS, Savage JJ, Anhalt H, Pavlakis S, Walvoord EC, Ten S \& Rhodes SJ. A novel LHX3 mutation presenting as combined pituitary hormonal deficiency. Journal of Clinical Endocrinology and Metabolism 200691 747-753.

62 Sobrier ML, Attie-Bitach T, Netchine I, Encha-Razavi F, Vekemans M \& Amselem S. Pathophysiology of syndromic combined pituitary hormone deficiency due to a $L H X 3$ defect in light of $L H X 3$ and LHX4 expression during early human development. Gene Expression Patterns 20045 279-284.

63 Pfaeffle RW, Savage JJ, Hunter CS, Palme C, Ahlmann M, Kumar P, Bellone J, Schoenau E, Korsch E, Bramswig JH, Stobbe HM, Blum WF \& Rhodes SJ. Four novel mutations of the LHX3 gene cause combined pituitary hormone deficiencies with or without limited neck rotation. Journal of Clinical Endocrinology and Metabolism 200792 1909-1919.

64 Sheng HZ, Moriyama K, Yamashita T, Li H, Potter SS, Mahon KA \& Westphal H. Multistep control of pituitary organogenesis. Science 1997278 1809-1812.

65 Machinis K, Pantel J, Netchine I, Leger J, Camand OJA, Sobrier ML, Dastot-Le Moal F, Duquesnoy P, Abitbol M, Czernichow P \& Amselem S. Syndromic short stature in patients with a germline mutation in the LIM homeobox LHX4. American Journal of Human Genetics 200169 961-968.

66 Lamolet B, Pulichino A, Lamonerie T, Gauthier Y, Brue T, Enjalbert A \& Drouin J. A pituitary cell-restricted T box factor, Tpit, activates POMC transcription in cooperation with Pitx homeoproteins. Cell $2001 \mathbf{1 0 4} 849-859$.

67 Liu J, Lin C, Gleiberman A, Ohgi KA, Herman T, Huang HP, Tsai MJ \& Rosenfeld MG. Tbx19, a tissue-selective regulator of POMC gene expression. PNAS 200198 8674-8679.

68 Pulichino AM, Vallette-Kasic S, Tsai JP, Couture C, Gauthier Y \& Drouin J. Tpit determines alternate fates during pituitary cell differentiation. Genes and Development 200317 738-747.

69 Pulichino AM, Vallette-Kasic S, Couture C, Gauthier Y, Brue T, David M, Malpuech G, Deal C, Van Vliet G, De Vroede M, Riepe FG, Partsch CJ, Sippell WG, Berberoglu M, Atasay B \& Drouin J. Human and mouse TPIT gene mutations cause early onset pituitary ACTH deficiency. Genes and Development 200317 711-716.

70 Vallette-Kasic S, Brue T, Pulichino AM, Gueydan M, Barlier A David M, Nicolino M, Malpuech G, Dechelotte P, Deal C, Van VG, de VM, Riepe FG, Partsch CJ, Sippell WG, Berberoglu M, Atasay B, de ZF, Beckers D, Kyllo J, Donohoue P, Fassnacht M, Hahner S, Allolio B, Noordam C, Dunkel L, Hero M, Pigeon B, Weill J, Yigit S, Brauner R, Heinrich JJ, Cummings E, Riddell C, Enjalbert A \& Drouin J. Congenital isolated adrenocorticotropin deficiency: an underestimated cause of neonatal death, explained by TPIT gene mutations. Journal of Clinical Endocrinology and Metabolism 2005 90 1323-1331.

71 Metherell LA, Savage MO, Dattani M, Walker J, Clayton PE, Farooqi IS \& Clark AJ. TPIT mutations are associated with earlyonset, but not late-onset isolated ACTH deficiency. European Journal of Endocrinology 2004151 463-465.

72 Weintrob N, Drouin J, Vallette-Kasic S, Taub E, Marom D, Lebenthal Y, Klinger G, Bron-Harlev E \& Shohat M. Low estriol levels in the maternal triple-marker screen as a predictor of isolated adrenocorticotropic hormone deficiency caused by a new mutation in the TPIT gene. Pediatrics 2006117 e322-e327.

73 Sornson MW, Wu W, Dasen JS, Flynn SE, Norman DJ, O'Connell SM, Gukovsky I, Carriere C, Ryan AK, Miller AP, Zuo L, Gleiberman AS, Andersen B, Beamer WG \& Rosenfeld MG. Pituitary lineage determination by the Prophet of Pit-1 homeodomain factor defective in Ames dwarfism. Nature 1996 384 327-333.

74 Gage PJ, Roller ML, Saunders TL, Scarlett LM \& Camper SA. Anterior pituitary cells defective in the cell-autonomous factor, $d f$, undergo cell lineage specification but not expansion. Development $1996122151-160$.

75 Tang K, Bartke A, Gardiner CS, Wagner TE \& Yun JS. Gonadotropin secretion, synthesis, and gene expression in human growth hormone transgenic mice and in Ames dwarf mice. Endocrinology 1993132 2518-2524.

76 Wu W, Cogan JD, Pfaffle RW, Dasen JS, Frisch H, O'Connell SM, Flynn SE, Brown MR, Mullis PE, Parks JS, Phillips JA III \& Rosenfeld MG. Mutations in PROP1 cause familial combined pituitary hormone deficiency. Nature Genetics 199818 147-149.

77 Deladoey J, Fluck C, Buyukgebiz A, Kuhlmann BV, Eble A, Hindmarsh PC, Wu W \& Mullis PE. 'Hot spot' in the PROP1 gene responsible for combined pituitary hormone deficiency. Journal of Clinical Endocrinology and Metabolism 199984 1645-1650.

78 Cogan JD, Wu W, Phillips JA, Arnhold IJ, Agapito A, Fofanova OV, Osorio MG, Bircan I, Moreno A \& Mendonca BB. The PROP1 2-base pair deletion is a common cause of combined pituitary hormone deficiency. Journal of Clinical Endocrinology and Metabolism $1998 \mathbf{8 3} 3346-3349$.

79 Turton JPG, Mehta A, Raza J, Woods KS, Tiulpakov A, Cassar J, Chong K, Thomas PQ, Eunice M, Ammini AC, Bouloux PM, Starzyk J, Hindmarsh PC \& Dattani MT. Mutations within the transcription factor PROP1 are rare in a cohort of patients with sporadic combined pituitary hormone deficiency (CPHD). Clinical Endocrinology 200563 10-18.

80 Duquesnoy P, Roy A, Dastot F, Ghali I, Teinturier C, Netchine I, Cacheux V, Hafez M, Salah N, Chaussain JL, Goossens M, Bougneres P \& Amselem S. Human Prop-1: cloning, mapping, genomic structure. Mutations in familial combined pituitary hormone deficiency. FEBS Letters 1998437 216-220.

81 Reynaud R, Chadli-Chaieb M, Vallette-Kasic S, Barlier A, Sarles J, Pellegrini-Bouiller I, Enjalbert A, Chaieb L \& Brue T. A familial form of congenital hypopituitarism due to a PROP 1 mutation in a large kindred: phenotypic and in vitro functional studies. Journal of Clinical Endocrinology and Metabolism $2004 \mathbf{8 9}$ 5779-5786.

82 Osorio MG, Kopp P, Marui S, Latronico AC, Mendonca BB \& Arnhold IJ. Combined pituitary hormone deficiency caused by a novel mutation of a highly conserved residue (F88S) in the homeodomain of PROP-1. Journal of Clinical Endocrinology and Metabolism $2000 \mathbf{8 5} 2779-2785$.

83 Lebl J, Vosahlo J, Pfaeffle RW, Stobbe H, Cerna J, Novotna D, Zapletalova J, Kalvachova B, Hana V, Weiss V \& Blum WF. Auxological and endocrine phenotype in a population-based cohort of patients with PROP1 gene defects. European Journal of Endocrinology 2005153 389-396.

84 Cogan JD, Wu W, Phillips JA III, Arnhold IJ, Agapito A, Fofanova OV, Osorio MG, Bircan I, Moreno A \& Mendonca BB. The PROP1 2-base pair deletion is a common cause of combined pituitary hormone deficiency. Journal of Clinical Endocrinology and Metabolism $1998 \mathbf{8 3} 3346-3349$.

85 Reynaud R, Barlier A, Vallette-Kasic S, Saveanu A, Guillet MP, Simonin G, Enjalbert A, Valensi P \& Brue T. An uncommon phenotype with familial central hypogonadism caused by a novel PROP1 gene mutant truncated in the transactivation domain. Journal of Clinical Endocrinology and Metabolism 200590 4880-4887.

86 Arroyo A, Pernasetti F, Vasilyev VV, Amato P, Yen SS \& Mellon PL. A unique case of combined pituitary hormone deficiency caused 
by a PROP1 gene mutation (R120C) associated with normal height and absent puberty. Clinical Endocrinology $2002 \mathbf{5 7}$ 283-291.

87 Fluck C, Deladoey J, Rutishauser K, Eble A, Marti U, Wu W \& Mullis PE. Phenotypic variability in familial combined pituitary hormone deficiency caused by a PROP 1 gene mutation resulting in the substitution of Arg-Cys at codon 120 (R120C). Journal of Clinical Endocrinology and Metabolism $1998 \mathbf{8 3} 3727-3734$.

88 Vallette-Kasic S, Barlier A, Teinturier C, Diaz A, Manavela M, Berthezene F, Bouchard P, Chaussain JL, Brauner R, PellegriniBouiller I, Jaquet P, Enjalbert A \& Brue T. PROP1 gene screening in patients with multiple pituitary hormone deficiency reveals two sites of hypermutability and a high incidence of corticotroph deficiency. Journal of Clinical Endocrinology and Metabolism 2001 86 4529-4535.

89 Mendonca BB, Osorio MG, Latronico AC, Estefan V, Lo LS \& Arnhold IJ. Longitudinal hormonal and pituitary imaging changes in two females with combined pituitary hormone deficiency due to deletion of A301,G302 in the PROP1 gene. Journal of Clinical Endocrinology and Metabolism $1999 \mathbf{8 4}$ 942-945.

90 Asteria C, Oliveira JH, Abucham J \& Beck-Peccoz P. Central hypocortisolism as part of combined pituitary hormone deficiency due to mutations of PROP-1 gene. European Journal of Endocrinology 2000143 347-352.

91 Pernasetti F, Toledo SP, Vasilyev VV, Hayashida CY, Cogan JD, Ferrari C, Lourenco DM \& Mellon PL. Impaired adrenocorticotropin-adrenal axis in combined pituitary hormone deficiency caused by a two-base pair deletion (301-302delAG) in the prophet of Pit-1 gene. Journal of Clinical Endocrinology and Metabolism $2000 \mathbf{8 5}$ 390-397.

92 Riepe FG, Partsch CJ, Blankenstein O, Monig H, Pfaffle RW \& Sippell WG. Longitudinal imaging reveals pituitary enlargement preceding hypoplasia in two brothers with combined pituitary hormone deficiency attributable to PROP1 mutation. Journal of Clinical Endocrinology and Metabolism $2001864353-4357$.

93 Bottner A, Keller E, Kratzsch J, Stobbe H, Weigel JF, Keller A, Hirsch W, Kiess W, Blum WF \& Pfaffle RW. PROP1 mutations cause progressive deterioration of anterior pituitary function including adrenal insufficiency: a longitudinal analysis. Journal of Clinical Endocrinology and Metabolism 200489 5256-5265.

94 Agarwal G, Bhatia V, Cook S \& Thomas PQ. Adrenocorticotropin deficiency in combined pituitary hormone deficiency patients homozygous for a novel PROP1 deletion. Journal of Clinical Endocrinology and Metabolism 200085 4556-4561.

95 Fofanova O, Takamura N, Kinoshita E, Vorontsov A, Vladimirova V, Dedov I, Peterkova V \& Yamashita S. MR imaging of the pituitary gland in children and young adults with congenital combined pituitary hormone deficiency associated with PROP1 mutations. American Journal of Roentgenology 2000 174 555-559.

96 Voutetakis A, Argyropoulou M, Sertedaki A, Livadas S, Xekouki P, Maniati-Christidi M, Bossis I, Thalassinos N, Patronas N \& Dacou-Voutetakis C. Pituitary magnetic resonance imaging in 15 patients with Prop 1 gene mutations: pituitary enlargement may originate from the intermediate lobe. Journal of Clinical Endocrinology and Metabolism $2004892200-2206$.

97 Parks JS, Brown MR, Baumbach L, Sanchez JC, Stanley CA, Gianella-Neto D, Wu W \& Oyesiku N. Natural history and molecular mechanisms of hypopituitarism with large sella turcica. Presented at the American Endocrine Society Meeting. New Orleans, June 24-27, Abstract no. P3-409 p 470, 1998.

98 Cushman LJ, Watkins-Chow DE, Brinkmeier ML, Raetzman LT, Radak AL, Lloyd RV \& Camper SA. Persistent Prop1 expression delays gonadotrope differentiation and enhances pituitary tumor susceptibility. Human Molecular Genetics 200110 1141-1153.

99 Bodner M, Castrillo JL, Theill LE, Deerinck T, Ellisman M \& Karin M. The pituitary-specific transcription factor GHF-1 is a homeobox-containing protein. Cell 198855 505-518.
100 Andersen B \& Rosenfeld MG. POU domain factors in the neuroendocrine system: lessons from developmental biology provide insights into human disease. Endocrine Reviews 2001 22 2-35.

101 Rhodes SJ, DiMattia GE \& Rosenfeld MG. Transcriptional mechanisms in anterior pituitary cell differentiation. Current Opinion in Genetics and Development 1994 4 709-717.

102 Li S, Crenshaw EB III, Rawson EJ, Simmons DM, Swanson LW \& Rosenfeld MG. Dwarf locus mutants lacking three pituitary cell types result from mutations in the POU-domain gene pit-1. Nature 1990347 528-533.

103 Andersen B \& Rosenfeld MG. Pit-1 determines cell types during development of the anterior pituitary gland. A model for transcriptional regulation of cell phenotypes in mammalian organogenesis. Journal of Biological Chemistry 1994269 29335-29338.

104 Rhodes SJ, Chen R, DiMattia GE, Scully KM, Kalla KA, Lin SC, Yu VC \& Rosenfeld MG. A tissue-specific enhancer confers Pit-1dependent morphogen inducibility and autoregulation on the pit-1 gene. Genes and Development 1993 7 913-932.

105 Tatsumi K, Miyai K, Notomi T, Kaibe K, Amino N, Mizuno Y \& Kohno H. Cretinism with combined hormone deficiency caused by a mutation in the PIT1 gene. Nature Genetics 19921 56-58.

106 Cohen LE, Wondisford FE, Salvatoni A, Maghnie M, BruckerDavis F, Weintraub BD \& Radovick S. A 'hot spot' in the Pit-1 gene responsible for combined pituitary hormone deficiency: clinical and molecular correlates. Journal of Clinical Endocrinology and Metabolism $1995 \mathbf{8 0} 679-684$.

107 Radovick S, Nations M, Du Y, Berg LA, Weintraub BD \& Wondisford FE. A mutation in the POU-homeodomain of Pit-1 responsible for combined pituitary hormone deficiency. Science $19922571115-1118$.

108 Kishimoto M, Okimura Y, Fumoto M, Iguchi G, Iida K, Kaji H \& Chihara K. The $R 271 \mathrm{~W}$ mutant form of Pit-1 does not act as a dominant inhibitor of Pit-1 action to activate the promoters of GH and prolactin genes. European Journal of Endocrinology 2003 148 619-625.

109 Pfaffle RW, DiMattia GE, Parks JS, Brown MR, Wit JM, Jansen M, Van-der-Nat H, Van-den-Brande JL, Rosenfeld MG \& Ingraham HA. Mutation of the POU-specific domain of Pit-1 and hypopituitarism without pituitary hypoplasia. Science 1992 257 1118-1121.

110 Pfaffle RW, Martinez R, Kim C, Frisch H, Lebl J, Otten B \& Heimann G. GH and TSH deficiency. Experimental and Clinical Endocrinology and Diabetes 1997105 (Suppl 4) 1-5.

111 Turton JPG, Reynaud R, Mehta A, Torpiano J, Saveanu A, Woods KS, Tiulpakov A, Zdravkovic V, Hamilton J, AttardMontalto S, Parascandalo R, Vella C, Clayton PE, Shalet S, Barton J, Brue T \& Dattani MT. Novel mutations within the POU1F1 gene associated with variable combined pituitary hormone deficiency. Journal of Clinical Endocrinology and Metabolism $2005904762-4770$.

112 Cohen LE \& Radovick S. Molecular basis of combined pituitary hormone deficiencies. Endocrine Reviews 200223 431-442.

113 Carvalho LR, Woods KS, Mendonca BB, Marcal N, Zamparini AL, Stifani S, Brickman JM, Arnhold IJ \& Dattani MT. A homozygous mutation in HESX1 is associated with evolving hypopituitarism due to impaired repressor-corepressor interaction. Journal of Clinical Investigation 2003112 1192-1201.

114 Coya R, Vela A, Perez de Nanclares G, Rica I, Castano L, Busturia MA, Martul P \& the GEDPIT group, . Panhypopituitarism: genetic versus acquired etiological factors. Journal of Pediatric Endocrinology and Metabolism 200720 27-36.

Received 13 March 2007

Accepted 10 May 2007 